\title{
The Short Story Cycle in Winseburg, Ohio
}

\author{
Liang Ling \\ Shaanxi Vocational \& Technical College
}

\begin{abstract}
The dual nature of the short story cycle: the interdependence within the tales and the independence of each tale is unique as a literary genre, yet this produces tension between the two. The interdependence within the Winesburg tales is analyzed from consistency of the framing devices and the consistency of mood; the independence is explored from the new looseness and the exclusive structure in Winesburg, Ohio.
\end{abstract}

KEYWORD: The short story cycle; independence; interdependence

\section{INTRODUCTION}

\subsection{A general review of Winesburg, Ohio}

Winesburg, Ohio, which Anderson had begun writing in 1915 and generally wrote in the order of the stories in the text, was published in 1919 and received much acclaim, establishing him as a talented modern American author. Winesburg, Ohio is "half individual tales, half long novel form", as the author himself described it. Writing in a simple, realistic language illuminated by a muted lyricism, Anderson dramatized crucial episodes in the lives of his characters. In this closely integrated collection of stories, he explores the loneliness and frustration of small-town lives. This work contains perhaps the most successful expression of the theme that dominates all Anderson's works - the conflict between organized industrial society and the subconscious instincts of the individual.

Winseburg, Ohio consists of twenty-five thematically related sketches and stories and almost each can stand as a biographical story of one protagonist; however, Winesburg, Ohio is unified by a single setting: Winesburg, the small Midwestern town; a recurrent character: George Willard, the young reporter on Winesburg Eagle, the only newspaper there; and a pervasive mood: of misunderstanding, loneliness, restlessness, disillusionment and dissatisfaction expressed in a colloquial and lyrical style. Though Anderson thought of the collection of short stories as a novel, Winesburg, Ohio appears to today's readers generally as a short story cycle rather than a novel.

\subsection{Major arguments of the paper}

This paper makes a theoretical study of the short story cycle as a genre and the discussion of the genre is illustrated with references to a typical American short story cycle: Winesburg, Ohio. The dual nature of the short story cycle, independence of each story and the interdependence of the stories, differentiates the cycle from the more tightly unified novel on one hand and the less coherent short story collection on the other.

Based on the generic characteristics of the short story cycle, the analysis goes to how unity is accomplished and how separateness is maintained in Winesburg, Ohio. The unity of the book is analyzed from two aspects: framing devices and themes. The framing devices introduces the framing story which stands as an introductory story and contains Anderson's principle concern in this book, "grotesques"; unifying protagonist, George Willard who is both an observer and a participant of the small town life. The book sounds many of Anderson's characteristic themes: the mixed nature of small-town American life, the warping power of material success and it is a significant expression of the psychological damage wrought by an industrial civilization - rendered with extraordinary compassion, but loneliness and alienation is the major theme of Anderson in this book.

The critical work done on the separateness of the book in this thesis is focused on what Anderson named the new looseness and the exclusive structure. This study takes into consideration, to a greater degree than earlier criticism, the short story 
cycle as an open work, emphasizing the totalizing strategies, on the one hand, and the tension between the independent stories and the unified work, between the discontinuity and fragmentation, on the other.

\section{THE THEORY OF THE SHORT STORY CYCLE}

\subsection{Generic evolution}

Throughout the history of literature there are cycles or sequences of tales, stories, novellas, lyric poems, plays and even novels, which provide writers different options for different subjects. The shortstory cycle - a literary genre as ancient as $A$ Thousand and One Nights and as modern as James Joyce's Dubliners - has rapidly ascended over the last century to become one of the dominant forms in American fiction. Most scholars and book reviewers, however, lack awareness of the short-story cycle's rich legacy in this country and consistently misconstrue new works of the genre as "novels" or "short story collections." The short story cycle did not develop until the mid-nineteenth century in many such works as Washington Irving's Legends of the Alhambra of the United States (1832) and Ivan Turgenev's A Sportsman's Notebook of Russia (1852). Although largely unrecognized by critics, the genre of the short story cycle has been employed by various writers to explore the divergence between writers and readers and to establish a contract between them. Ian Reid argues in his book on the short story, "Probably the impulse to combine individual tales into larger wholes has its origin in the very nature of imagination itself (461)". The short story cycle does not rely on such familiar literary forms of narration as plot, temporal continuity or chronological order which usually "tell" a story. The short story cycle, as some critic theorists argue, is a hybrid genre of autonomous short story and the novel (e.g. Luscher, Robert M. in his "American Regional Short Story Sequence" 2).

When such works as James Joyce's Dubliners (1914), Sherwood Anderson's Winesburg, Ohio (1919) and Ernest Hemingway's In Our Time (1925) and William Faulkner's Go Down, Moses (1942) first came out, they did make a big noise, and critics became more concerned with the generic labels. However, critics often find it is convenient to discuss such short story collections as "episodic" or "apprenticeship" or "fragmentary" novels or "story novels", labels which help them to trace the development of the novelists. The short story cycle is still critically under- examined and often overlooked. Much critical study had been made from thirties to fifties in the last century, and some critics (eg. Malcolm Cowley) suggested that they were neither novels nor short story collections.

It is until the seventies in last century that critics begin to offer systematic descriptions of this distinct genre, defined as different from both the short story and the novel but taking the advantage of the conventions associated with each. One of the most prominent critics on this aspect is Forrest L. Ingram whose work, Representative Short Story Cycles of the Twentieth Century in 1971, is a groundbreaking book representing the first full-length study of the short story cycle ( or short story sequence in his name) and its influences transcend national boundaries. Ingram has influenced many critics such as Martha Mulray Curry and Joseph Fontenrose, all devoted their studies on the short story cycle as a distinct genre. In 1989, Susan Garland Mann published his work, The Short Story Cycle - A Genre Companion and Reference Guide, which exams some representative works of the short story cycle. The Composite novel: The short Story Cycle in Transition (1995) by Maggie Dunn and Ann Morris discusses the 200-year history of the literary genre. James Nagel's work in 2000, The contemporary American short Story cycle, is a very recent study of this kind from American perspective and offers the first systematic history and definition of the story cycle as exemplified in contemporary American fiction, bringing attention to the format's wide appeal among various ethnic groups.

\subsection{Generic Characteristics}

The stories within a cycle are individually complete, which enables readers to understand each of them without going beyond the limit of the individual story. For example, many stories in Winesburg, Ohio such as "Hands", "Paper Pills" were published independently before 1919; nevertheless, the stories are interrelated, when work together, they could produce something that can not be achieved in a single story. Therefore, the interdependence of the stories and the independence of each story are essential characteristics of the short story cycle as a literary genre, however, the tension between the two within the cycle can never be ignored.

\subsubsection{Interdependence of the Stories}

Forrest Ingram introduces the terminology of the short story cycle on the basis of method of composition and the author's intention. He divides cycles into the arranged cycle, the composed cycle and the completed cycle.

The composed cycle, conceived of as a cycle from the time the first story was written, and as a result, generally tightly organized. [...] The completed cycle, generally less unified, conceived of only after 
some of the stories have been written. [...] The arranged cycle, the most loosely conceived of by the author and the editor only after all of the stories have been written. (17-8)

Therefore, no matter which category it is, stories within the cycle are unified but differ in degree and vary from book to book and writer to writer. Writers frequently commit themselves to cycles from the very start, or after writing one or two stories or come to answer that the stories may be combined to cycle when all had been written. What is of great importance is that there must be connections to make the stories unified to some extent. A story within a short story cycle does not stop with the last word of the story, but is connected to other stories in the cycle.

Interdependence of stories within a cycle can be easily perceived, for there usually some unifying devices and patterns contained in short story cycles: the single setting, both the places and the historical period, shared characters and also unified mood created. Simply put together, stories may explore the shared life of a group of people instead of one or two protagonists.

\subsubsection{Independence of Each Story}

As it is mentioned in the previous passages, the short stories composing a cycle are inexorably linked but free-standing at the same time, "the parts of the composite novel are likely to be immediately as short stories--- each one titled and self-contained, able to be experienced independently by reader, perhaps becoming well-know in its own right as it is anthologized on other collections" (Dunn and Morris 11).

Each story as the part of the cycle stands as important as the book' overall effect, unlike novel, in which the importance of the part predeterminedly subordinated to the whole. If read alone, each individual story is self-sufficient and complete, and readers can not sense its connectedness with the stories that proceed and follow.

In the process of novel reading, readers frequently find the abrupt transitions between chapters in time, space or point of view; however, the transitions between chapters in novels can never be as demanding as in those between stories in cycles. The cycle readers must leave behind the self-contained and completed world of one story before entering the next independent story. What has been changed may not only be space or point of view, but also the characters and mood created.

"The Book of the Grotesque" in Winesburg, Ohio is a clear example for it is more a sketch of the whole book rather than an autonomous story. Thus concerned with the separateness of stories from a short story cycle, one must be inclusive rather than exclusive. In most cases, the end of each story creating a sense of finality or closure though what can be achieved within the cycle may be minimized a lot.

\subsubsection{Tension between the Independence and the Interdependence}

The stories within the cycle are autonomous units governed by their own principles while they are integral parts of larger whole simultaneously. But when do the many cease being merely many and congeal into one and when does a "one" become so discrete and differentiated that it dissolves into a "many"? Thus "the short story cycle must maintain a balance between the individuality of each of the stories and the necessities of larger unit" (Ingram 15), but the "balance" is not able to be quantified.

By the short story cycle, the writers usually present the readers a series interlocking stories and the readers are expected to approach the texts in such a manner. However, the overall meaning of the cycle changes with the variable understanding that a reader may have of any given story whose meaning may be encouraged to extend beyond its own border by the extra-story interconnection.

If the "mission of the novel [is] to see and illustrate the interconnectedness of things" (Harris $185)$, the short story's mission is to see and illustrate the disconnectedness of things. What is the short story cycle's mission? The tension becomes apparent in the way readers respond it.

Then, what if when a seemingly independent story is read within the cycle of the short stories? If the character in a novel approaches the whole of the life, but the short story focuses on a moment of life, the short story cycle represents significant moments in lives of multiple characters, repeated and again, from story to story.

\section{THE CYCLE IN WINESBURG, OHIO}

\subsection{Consistency of the Framing Devices}

\subsubsection{Framing Story: The Book of the Grotesque}

Anderson originally planned to title his collection "The Book of Grotesque" with the subtitle "A Group of Tales of Ohio Small Town Life" until the publisher suggested Winesburg, Ohio to which Anderson agreed, but the theme of the grotesque is still the focus of his writing. The inhabitants of Winesburg exist in a rural wasteland that is in a state of decay and under the threat of extermination by the industrial age when the old good values of life have been destroyed by the industrial dispensation; that people have been cut off from each other and even 
from themselves, and they were left vulnerable, nervous and struggling.

The ultimate unity of the book is a unity of feeling. Anderson discovered these lonely and deformed souls who would never be able to escape from their marginalized world; he found concealed reserves of feeling, of muted torment and love.

\subsubsection{Unifying Protagonist: George Willard}

The presence of the perceptive observer, George Willard, plays a very essential role in the unity of the Winesburg tales. George Willard is the major character in the last tale "Departure", but he keeps appearing in almost every story, and to whom the town's inhabitants bring their stories, confide their hopes, dreams and even fears.

The effort the grotesques made to establish intimate relations with him is discernible in about half of the stories. Though not the most important individual in Winesburg, he is necessarily the most important actor in the lives of other Winesburgers, no matter as a listener or a participant, he is approached by these grotesques who reveal their secrets to him.

Moreover, George Willard's growth as an artist to maturity also serves as unify device. George's maturity has of course been coming on for a long time. Early in the book such as "Hands", "Paper Pills" and "Mother", George and his background are introduced; and other stories thereafter are arranged to trace the develop George's growth as young artist, and relations with women as in "Nobody Knows", "The teacher", "An Awakening", and "Sophistication". George attempts to resolve the conflict between the practical world of affairs and world of dreams, with its emphasis on imaginative creativity and its definition of success in terms of the degree of penetration into the buried life of others. Everyone is ready to give George some advice. In "The teacher", Kate Swift, his former teacher, tries to tell him "some conception of the difficulties he would have to face as writer" (WO 121), "to know" the life rather than "fooling the words" and warns him not to "become a mere peddler of words" (WO 121).

\subsection{Consistency of Theme}

In Winesburg, Ohio, Anderson is preoccupied with a need to describe the plight of the "grotesques": the unsuccessful, the deprived and the inarticulate. He sensitively depicts mental poverty and eccentricity by the timeless cycle of short stories. Anderson exposes the emotional undercurrents that bind people together.

As a whole, Winesburg, Ohio is a cycle of different "misses": of mismarriages as in "Mother", of misunderstanding as in "Hands", of misfits as in "Paper Pills', of mistakes as in "Queer", of misfortune as in "Godliness".

In Winesburg, Ohio, Anderson pictured men and women as everything except full human beings. He was sensitive to the taste and feel of life and he trembled at every sign he found of it. His characters, be they wistful and frail, express certain outcast aspects of life. With his comments about industrialism, sexual repression, Puritanism and materialism, Anderson stands as a spokesman against these anti-individual values and for a new liberation.

\section{CONCLUSION}

Winesburg, Ohio remains an influential work, and one can hardly examine the genre of the short story cycle without taking it into account.

Anderson employs the short story cycle, a form of new looseness, to delineate the miserable existence of the inhabitants in American Midwestern small towns during the initial period of industrialization. The form seems simple but expressive. The autonomy of each story and the wholeness of the cycle coincide with the alienation and fragmentation of the Winesburg dwellers. Industrialization dehumanized them and reduced them into grotesques who sticks to the absolute truth and lost the ability to communicate. Anderson exposed the sadness of the reality, which resulted, he believed, from the destructive, dehumanizing nature of the factory and rapidly advancing technology.

When Sherwood Anderson presented his experiment on the new form, the short story cycle, he not only gained the international recognition as an important voice in American literature, but also influenced the generation of the young writers after him. No analysis from single aspect could exhaust such a great work, and the echoes of Anderson's legacy will continue to reverberate.

\section{REFERENCES}

[1] Abrams, M.H. A Glossary of Literary Terms. 7th ed. 2004. New York: Thomson Learning.

[2] Anderson, David D. Crictical Essays on Sheroow Anderson. 1981. Boston: G.K. Hall \& Company.

[3] Anderson, Sherwood. Winesburg, Ohio. 2004. Shanghai: Shanghai Foreign Language Education Press,.

[4] ---. The Letters of Sherwood Anderson. Howard Munford Jones \& Walter B. Rideout. eds. 1953. Boston: Little.

[5] ---. Sherwood Anderson's Memories, Vol. 19 of the Complete Works of Sherwood Anderson. Kichinsuke Ohashi. ed. 1982. Kyoto: Rinsen Book Co.

[6] Cowley, Malcolm. "Intoduction." Winesburg, Ohio. By Sherwood Anderson. Sherwood Anderson Winseburg, 
Ohio Text and Criticism. John H. Ferres, ed. 1966.Michigan: The Viking Critical Library, a Penguin Book.

[7] Dunn, Maggie and Ann Morris. The Composite Novel: The Short Story Cycle in Ttransition. 1995. New York: Twayne.

[8] Ingram, Forrest L. Representative Short Story Cycle of the Twentieth Century.1971.Hague: Mouton \& Co.

[9] Luscher, Robert M. "American Regional Short Story Sequence." Diss. Duke U, 1984. Disscussion of Short Story Sequence. Short Story Criticism Papers \&
Roundfable. Sixth International conference on the Short Story in English. 2000. Iowa: Unversity of Iowa.

[10] Mann, Susan Garland. The Short Story Cycle A Genre Companion and Refencence Guide. 1989. Westport: Greenwood Press.

[11] Nagel, James. "The American Short Story Cycle." The Columbia Companion to the Twentieth-century American Short Story. Blanche H. Gelfan. ed. 2000. New York: Columbia UP.

[12] Reid, Ian. The Short Story. The Critical Idiom 37. 1977. London: Methuen. 